induced my surprise that he referred only to Ancoats Hospital and omitted all reference to the Salford Royal Hospital when considering the effects of the removal of the infirmary to its new buildings. Your Manchester correspondent evidently regards the centre of the population as the centre of the city. The fact is that Manchester and Salford are only separated by a narrow, filthy river, and in some places only by a landmark. They would now be under a single corporation if the people could have their way. They consist of one great community of nearly a million people, and in spite of police instructions and ambulance arrangements accidents and emergencies have a tendency to gravitate to the nearest general hospital, and will continue to do, whatever the artificial restrictions now in vogue may try to accomplish.-I am, etc.,

Manchester, July 7th. ANDREW BOUTFLOWER.

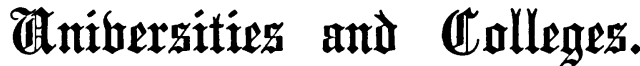

\section{ROYAL COLLEGE OF SURGEONS OF ENGLAND.} Council Election.

THE election of members of Council to fill the four vacancies made by the retirement of Mr. Ward Cousins, Mr. Pearce Gould, and Mr. Harrison Cripps and the resignation of Mr. Marsh, was held on Thursday, July 2nd.

The result was as follows :

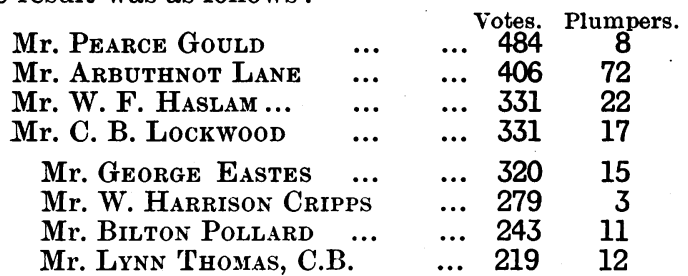

The total number of votes amounted to 866-namely, voting papers, valid, 843 , too late 9 , otherwise invalid 1 , personal votes 13 .

Mr. Haslam and Mr. Lockwood received the same number of votes. The latter being junior on the roll of Fellows is the substitute member for Mr. Howard Marsh until 1910.

The President declared Mr. Pearce Gould duly re-elected, and Mr. Arbuthnot Lane, Mr. Haslam, and Mr. Lockwood duly elected members of Council.

\section{UNIVERSITY OF CAMBRIDGE.}

THE Raymond Horton-Smith Prize for 1908 has been awarded THE Raymond Horton-Srith Prize for 1908 has been awarded degree on Control of the Sphincters in Nervous Lesions. The following have received honourable mention: J. M. Hamill, M.A., Trinity College; H. Beckton, M.A., Clare College.

\section{UNIVERSITY OF BIRMINGHAM}

THE following candidates have been approved at the examina tions indicated :

First M.B., Сн.B. (Chemistry, Physics, and Biology).-Class IT ${ }^{*}$ G. H. Alabaster, N. A. Austin, R. A. Broderick, *E. F. Buckler, tEisie M. Humpherson, J. C. Jones, J. B. Lowe, H. C. Nichson, †P. T. Priestley, J. A. Scott, H. Sheasby, $\pitchfork$ C. L. Spackman.
*Biology only.

Second M.B., Ch.B. (Anatomy and Physiology).-Class I: ${ }^{*}$ G. E. Elkington, "A. A. Wilkinson. Class II: R. B. Coleman, E. Davies,

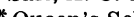

ThInd M.B., Ch.B. (Pathology and Bacteriology, and Materia Medica and Pharmacy).-Class I: "C. Walker. Class II: E. W. " Aunes Scholarbip. I Pathology and Bacteriology.
ing

Fodrth M.B., Ch.B. (Forensic Medicine, Toxicology, and' Public Health).-Class $\mathrm{I}$ : Mary Clarke, *H. H. F. Humphreys. Class II : W. C. Blackham, N. A. Boswell, H. G. Browning, J. S. Edwards, Violet MI. McCready, C. E. Molino, H. H. Sampson, C. J.
Thomppson, Ethel A. Waldron, H. A. Whitcombe, K. D. Wilkinson. $\quad$ * Queen's Scholarship.

Final M.B., CH.B.-Charlotte Bailey, J. Dale, E. T. Gaunt, E. V. Whitby, N. v. Williams.

M.D.-R. A. Lyster; N. J. L. Rollason, Helen G. Stewart.

D.P.H. (Parts I and In.-R. Burnet, W. D. Carruthers, N. Wilks: * Part I only.

† Part II only.

\section{UNIVERSITY OF DUBLIN.}

THE following candidates have been approved at the examinations indicated :

Preimintary Sctentific (Botany and Zoology).-*W. H. R. M'Carter, "J. N. Armstrong, *W. O. W. Ball, ${ }^{*} \mathrm{H}$. G. Trayer, ${ }^{*}$ C. C. Mecredy, G. Roe, "F. A. V. Denning, C. D. Goodenough, J. Colgan, J. H. Counihan, H. L. D'O. Duckworth, W. Crane, E. S. Johnson, R. E. Tottenham, Jane F. Colquhoun, J. Coulter, E. F. O'Connor, W. P. Croker, T. J. Magee, Kathleen D. Wallace, J. A. MacMahon, K. R. Drury, J. H. Grove-White, M. Horan, R. O. Smyth, A.P.
Draper, J. B. Taylor, O. V. Burrows, H. W. Browne, J. S. English, Draper, J. B. Taylor, O. V. Burrows, H. W. Browne, J. S. English,
J. R. Dobson, T. V. Oldham, R. A. Stewart, R. Hemphill, G. M. M: J. R. Dobson, T. V. Oldham, R. A. Stewart, R. Hemphill, G. M. M.
Fleming, E. G. Fishe, L. J. Nugent, E. C. Crichton, R. H. Lyons, Fleming, E. G. Fishe, L. J. Nugent, E. C. Crich
J. A. Maxwell, A. W. D. Magee, H. B. F. Dixon.

PReLTMTNary ScIENTIFIC (Physics and Chemistry) $-{ }^{*} \mathrm{H}$. T. Batee, ${ }^{*}$ G. H. Culverwell, Eileen M. Hewitt, C. W. C. Myles, W. H. R. M'Carter, E. H. Wilkins; Dorothy K. Milne, G. Roe, J. Colgan, W. Crane, J. H. Counihan, W. M. Johnstone, Jane F. Colquhoun, Trayer, C. D. Goodenough, G. A. Hoffman, W. E. Fetherstonhaugh, K. K. Drury.

INTERMEDIATE (Part $n$.- ${ }^{*}+H$. L. W. Woodroffe, A. A. Louw, J. M. Elliott, R. W. Murphy, A. F. B. Shaw, F. C. Crosslé, W. L. Eng lish, T. L. B. Bookey, A. E. Malone, T. G. Harpur, T. W. E.
Henry, E. N. Bateman, R. T. Vaughan, H. M'C. Fleming, w. O. Halpin, B. G. Quinlan, M. Moore, H. P. Harpur, R. E. Lee.

Intermediate (Part II). A. A. Louw, C. W. M'Kenny, C. Pentland, F. J. A. Keane, W. O. Halpin, E. W. G. Young, J. Gardiner,
H. R. M. Ferguson, E. P. Allman-Smith, G. Scroope, R. P. Pollard, R. E. Lee.

Final (Part $D$ ). - T. A. Hughes, *A. J. Stals, *D. Duff, *D. M. Moffatt, ${ }^{*}$ R. E. T. Tatlow, V. B. Kyle, E. J. Powell, C. P. Smyly, A. A. M Connell, C. G. S. Baronsfeather, J. E. N. Ryan, H. R. Kenny, C. B. Jones.

Final (Part II, Surgery) - - D. P. Clement, " A. V. J. Richardson, " D. G. Madill, "J. C. Pretorius, E. C. Lambkin, S. F. A. Charles, C. A. L. Hahn, D. F. Hunter, R. P. Hadden, J. E. M'Causland, E. J. H. Garstin, W. Knapp, W. H. Sutcliffe.

* Passed on High Marks. t Purser Medal.

UNIVERSITY OF EDINBURGH. A Correction.

IN the British Medical Journal of July 4th, p. 57, among the candidates approved at the M.B., C.M. (Old Regulations) examination, the name and rank of G. Bidie, Major, I.M.S., were, we regret, inadvertently printed as " $\mathrm{G}$. Bidie, Captain, I.M.S."

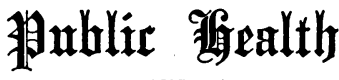 AND}

\section{POOR-LAW MEDICAL SERVICES.}

YELLOW FEVER IN CUBA.

THE elaborate and carefully compiled publication known as the Informe Mensual, or Sanitary Report of the Island of Cuba, in the two last monthly issues, of February and March, now to hand, gives the latest information as to the prevalence of yellow fever in the island. During February only two cases of the disease occurred among the civilian population, but a small epidemic broke out at Santa Clara among the United States troops quartered in that city. The strenuous measures token troops quartered in that city. The strenuous measures taken however, resulted in success, and no further cases developed
during March. It is now the boast of the Sanitary Department during March. It is now the boast of the Sanitary Department that not even a mild attack can occur without its being recog-
nized by the medical officers. The mosquito brigades are nized by the medical officers. The mosquito brigades are
organized to the highest degree of efficiency, and whenever and organized to the highest degree of efficiency, and whenever and wherever mosquito larvae are met with in any house in the oity
of Havana the owner is formally notified, the house is kept of Havana the owner is formally notified, the house is kept under observation, and if the larvae are again found, the owner
is immediately fined-a proceeding which seems to have had a remarkable effect in getting rid of all species of these insects.

REPORTS OF MEDICAL OFFICERS OF HEALTH. Metropolitan . Borough of Chelsea.-The estimated popula-
tion of Chelsed was 74,857 . The birth-rate was 19.2 per 1,000 , tion of Chelsea was 74,857. The birth-rate was 19.2 per 1,000, the death-rate 15 per 1,000 and the infantile mortality-rate 124 per 1,000 births. As in former reports, Dr. Louis Parkes gives vital statistics relating to special classes of the popula-
tion which are of very great interest. In the industrial dwellings, which have a population of 3,150 persons, the birth-rate was 31 per 1,000 , the death-rate 12.4 per 1,000 , and the infantile mortality-rate equal to 71 per 1,000 births. In 11 poor-class streets and courts with an aggregate population of 4,130 persons, the rates were 41.4, 26.6, and 204 respectively. During 1907 there were demolished or vacated for demolition in the borough of Chelsea 99 houses, displacing a popula-
tion of nearly 600 persons. Earl Cadogan, K.G., has offered the borough council the freehold of a plot of land nearly half an acre in extent for the purpose of erecting upon it houses for an acre in extent for the purpose of erecting upon it houses for
the working classes. The land is offered free of cost and upon certain conditions as to the setting back of the building line, and that the dwellings to be erected shall be used by the 